\title{
Causes of Landslide and its Socio-economic Effects: a study on Chattogram City and Surrounding Areas, Bangladesh
}

\author{
Md. Jahangir Ali \\ Urban Development Directorate, Bangladesh \\ Correspondent: jahangir_ali65@yahoo.com
}

$\begin{array}{ll}\text { Received } & \text { : August 08, } 2021 \\ \text { Accepted } & \text { : August 25, } 2021 \\ \text { Published } & \text { : October 31, } 2021\end{array}$

Citation: Ali, V.J. (2021). Causes of Landslide and its Socio-economic Effects: a study on Chattogram City and Surrounding Areas, Bangladesh. Ilomata International Journal of Social Science, 2(4), 275-286. https://doi.org/10.52728/ijss.v2i4.393

\begin{abstract}
Landslide is a regular hazard in Bangladesh especially in Chattogram, the South-Eastern part of the Country. In 2007 and 2008 there happened two massive landslides in Chattogram. As a result, a huge number of people (130 and 11 respectively) died with heavy loss of properties affecting thousands of people in the region. Most of the landslides happened after torrential rain. Combined effect of rainfall and hill cutting induced slope instability adding Earthquake-triggered landslide in Chattogram. Some influential people are involved in hill cutting and developing hilly settlements in Chattogram. In some places, Government and non-Government authorities are developing settlements by razing hills there. A detailed area planning, landslide vulnerability zoning, landslide database development, geophysical analysis and strictly implementation of Government's existing rules are recommended to ensure avoiding further tragedy in Chattogram like 2007 and 2008.
\end{abstract}

Keywords:

\section{INTRODUCTION}

Landslide or often called ground movement is a geological event that occurs due to the movement of rock or soil masses of various types and types such as the fall of rocks or large lumps of soil. In general, landslides are caused by two factors, namely driving factors and triggering factors. The driving factors are the factors that affect the condition of the material itself, while the trigger factors are the factors that cause the material to move (Carabella et al., 2022; Chen et al., 2021).

Although the main cause of this incident is gravity which affects a steep slope, there are other factors that also play a role; (1) erosion caused by surface runoff or rainwater, rivers or ocean waves eroding the foot of steeper slopes; (2) slopes of rock and soil are weakened through saturation caused by heavy rain; (3) earthquakes cause vibrations, stress on mineral particles and weak areas in rock and soil masses that cause the landslides of these slopes; (4) volcanoes create sparse dust deposits, heavy rains and dust flows; (5) vibrations from machinery, traffic, use of explosives, and even lightning; (6) excessive weight, for example from gathering rain or snow. (Liu et al., 2021; Meghanadh et al., 2021) 
The type of surface of an area determines the risk of landslides. Sloping areas tend to be prone to landslides. The steeper the slope, the greater the possibility of landslides. Areas with a less dense soil structure as well as less strong rocks also increase the landslide conditions of an area. Water, either rain water or flood water can be one of the causes of landslides. When it rains heavily or floods, water will seep into the ground and make the sediment heavier. Water then accumulates at the base of the slope causing lateral movement. This movement causes heavy sediment to move and then landslides occur. A sudden drop in water level can also cause landslides. For example, a lake or river that suddenly recedes, the surrounding soil wall will suddenly lose its support. This makes the area that was initially soaked in water will experience landslides. (Pawluszek-Filipiak et al., 2021; Wistuba et al., 2021)

Earthquakes vibrate the earth's surface, making soil, rocks, and buildings move, causing landslides on unstable surfaces. The number of landslides caused by earthquakes increases with the increase in the magnitude (strength) of the earthquake. The greater the strength of the earthquake, the more landslides will occur. In addition to earthquakes, ground vibrations can also cause landslides. Examples of vibrations that can cause landslides are the vibrations of collapsing buildings, vibrations, motor vehicles, and also vibrations resulting from exploding bombs. (Bounab et al., 2021; Panchal \& Shrivastava, 2021)

Landslide incidents are frequently occurring in Chattogram, Bangladesh and its surrounding areas almost every year. Landslide is one kind of Chittagong, the density of population, type of settlement, economic activities and other development activities it is quite different from other parts of the country. In course of time, everything is changing in Chittagong. Due to change in natural features, some dangerous incidents like landslide occurring every year, which is increasing at an alarming rate in recent years. In 2007, in such a landslide, about 128 people died, which is a great concern to the whole nation. (Abedin et al., 2020; Islam, 2017)

There is a great impact on man environment and on the socio-economic conditions of the people living at the concern area. This is why, a research work is needed to find out the causes of landslide, it`s impact on man and environment and to make some proposals the concerning authority, so that, any kind of loss could be kept at a minimum lever in future years.geological phenomenon. There are mainly two grater districts (Chittagong \& Chittagong Hill Tracts) in Bangladesh, which are almost covered by hills Landslides are occurring frequently in these regions in recent years. As a result. agreat loss of lives and properties are being happened with this incident. Hundreds of hillsexist here. So, the landforms of Chittagong differ from rest of the country. (Ahmed, 2021)

The core objectives of the research are to find out the causes of landslide and its socio-economic effects on people and society, and to formulate some policies so that landslides could be kept at a minimum level in future.

\section{METHOD}

The study was conducted through comprehensive structured interview by means of well reformed questionnaire. The data was collected from both primary and secondary sources to strengthen the rationality of the study and for better and comprehensive analysis. The study was conducted at Kaibalyadham, Khulshi, Motijharna of Bangladesh Railway Colony, ShahidMinar area of Chittagong University, Lebubagan and Kachhaghona of Chittagong Cantonment area of Chittagong City in Bangladesh during 27 to 29 April 2009. In this research 49 respondents were selected by random sampling procedure. Proportional percentages were calculated in terms of specific category were followed to give the research a proper logical quantitative ground. In addition, Topography \& geological formation of the study area and climatic issues have been analyzed. 


\section{RESULT AND DISCUSSION}

\section{Rationality of this Study}

After massive landslides in 11 June 2007 in Chittagong, it seems that a geographical research should be done to find out the causes behind landslide incidents. This approach mostly emphasized on 'Geo-social' characters of disasters regarding weather, climate change, global warming, ecology, social change, urbanization and settlement pattern.

After every landslide incident some common talks are to be heard. Some people say that it is "Hill cutting" the only reason behind the landslide incidents. Some people add, Heavy Rainfall and Flash flood of its supplementary causes.

On the other hand, there is a great impact on landslides in socio-economic aspects. Affected people have to suffer a long. In most of these cases, affected people have to suffer till the end of life. The society does a very little for them. Government has to pay a lot and has a great concern about this incident, because Government itself has a responsibility.

In recent years, landslide incidents are being happened frequently. Heavy loss of life and wealth are being occurred. It has a great socio-economic importance. At the same time, hilly eco- system is breaking down and environmental degradation is continuing.

Now, it is a national concern to the Government and to the researchers. This is why, it can be said that the selected research work has a great social and national importance, Moreover, in this research paper some recommendations have been made as remedies/ mitigating measures for future work formulation of the Government to carry on research related to urbanization and settlement. The landslide incidents, which occurred in Chittagong city and its surroundings in $2007 \& 2008$, are directly related to Urbanization and Urban settlement. So, it can be said that to select this research work is very logical and well timed.

\section{Limitations of the Study}

The study area (Chattogram city) was far away from my work place (Dhaka). Where the topography is different and was a new experience for me. I had to go through some complex situations. Due to lack of manpower and financial fund the survey work could not be elaborated.

\section{Geographical Description of the Study Area}

Chittagong city is the second largest city of Bangladesh. It is situated within $22^{\circ}-14^{\circ}$ and $22^{\circ}-24^{\circ}$ -

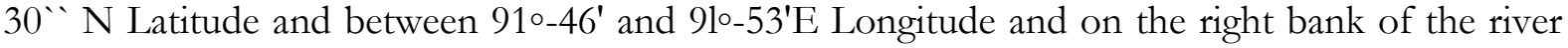
Karnaphuli. Chattogram City consists of six thanas, 68 wards and 236 mahallas. [It has an area of 209.66 sq. $\mathrm{km}$. The city has a population of 3202000 ; male $54.37 \%$ and female $45.63 \%$, population density per sq. $\mathrm{km} 15272$.

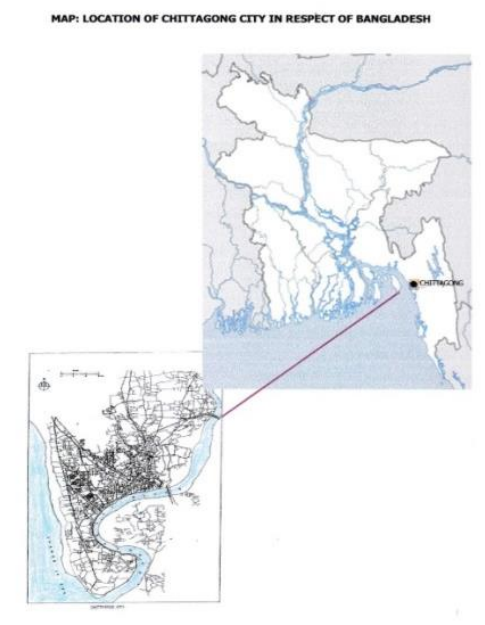




\section{Topography and Drainage}

Chattogram is very different in terms of topography, with the expansion of Sylhet and northern Dinajpur, from rest of Bangladesh, being a part of the hilly regions that branch off from the Himalayas. This eastern offshoot of the Himalayas, turning south and southeast, passes through Assam and Tripura state and enters Chittagong across the river Feni. The range loses height as at it approaches Chittagong city and breaks up into small hillocks scattered all over the city. This range appears again on the southern bank of the Kamaphuli River and extends from one end of the district to the other. Chandranath or Sitakunda is the highest peak in the district. With an altitude of I152 feet above mean sea level. Nagarkhana to the north of Chittagong town is 289 feet high. In the city itself, there is a peak known as Batali Hill, Which used to be 280 feet high and is the highest point in the town. There was a light post at the top of Batali Hill for the guidance of vessels far away in the sea. This famous hill, like other beautiful hills and hillocks in the city of Chattogram, is being gradually leveled up and reduced in height for the construction of houses.

Chattogram district possesses no natural lakes. As a result, several artificial lakes and ponds or dighis, as they are popularly known are found all over the district. A large number of dighis big and small, were dug during the Muslim period. The most popular reason given for the presence of such a large number of ponds is that during the Muslim period it was felt necessary to provide ponds for the use of the womenfolk of the city. Therefore, almost every well-to-do house had a pond or a dighi. Among the big ponds in Chattogram city mention may be made of Laldighi, Kamal Daha's dighi, Ashar Khan`s dighi and Belowa dighi. Many of these dighis have been filled up. Laldighi is still an important place. A boundary wall has protected the entire dighi. Most of the large public meetings in Chattogram are held in the field next to Laldighi. This field is known as the Laldighi Maidan. The Assam Bengal Railway dug two artificial lakes (in 1920 and 1924) near the Pahartali Railway station. These lakes served as reservoirs to supplely water to the Railway. Foy's lake was dug in 1924 and was named after the Railway engineer Foy. Both the lakes are places of attraction because of their beautiful location.

The entire district of Chattogram possesses with many natural springs. The sources of most of these springs are to be found inthe hill ranges. The water from these springs is used for irrigation purposes as well as to supply drinking water. In the city there are a number of springs. which are bounded by concrete walls by the Municipal authorities and supply drinking water.

\section{Soil and Soil Condition}

The soil in this area classified into seven categories according to the 1964-66 forestal survey. The most important ones are clay loam, sandy loam and silty clays. The most extensive is silty clay loam, which covers $67 \%$ of the total area. Almost all the soils have fertility. All the non-alluvial soils and some of the alluvial soilsshow coarse textured surface material and the water holding capacity of most of the extensive soils is very low. Grass and Scrub occupying this hilly land. The hill soils are mainly yellowish brown to reddish brown loams which grade into broken shale or sandstone as well as mottled sand at a variable depth. The soils are very strong acidic.

\section{Climate}

The climate of this region is characterized by tropical monsoon climate with mean annual rainfall nearly $254 \mathrm{~cm}$ in the north and east, and $254 \mathrm{~cm}$ to $381 \mathrm{~cm}$ in the south and west. The dry and cool season is from November to March; Pre-monsoon season is April which is very hot and sunny and the monsoon season is from June to October, which is warm, cloudy and wet. Annual average temperature maximum $32.5^{\circ} \mathrm{C}$, minimum $13{ }^{\circ} \mathrm{C}$, total annual rainfall $2687 \mathrm{~mm}$. 


\section{Vegetation}

The hills are unsuitable for cultivation but natural vegetation remains widely. Jhum cultivation is being practiced on the hill slopes. Cotton, rice, tea and oil seeds are raised in the valleys between the hills.

\section{Flora}

The hills, rivers and cliffs are covered with dense bamboo breaks, tall trees and creeper jungles. The valleys are covered with thick forest. The vegetation is characterized by semi evergreen (deciduous) to tropical evergreen dominated by tall trees belonging to Dipterocarpaceae, Euphorbiaceae, Lauraceae, Leguminacac, and Rubiaceae.

\section{Fauna}

The fauna mainly includes monkey, fox, jungle cat, fishing cat, wild boar, land turtle, king cobra, reticulated python, rat, snake and other non-poisonous snakes together with large number of species of lizards and amphibians like frog and toad and tree frogs. More than 60 families of birds are found.

\section{Economic Activities}

According to Bangladesh Bureau of Statistics (BBB) the main occupations of the people of Chattogram are Agriculture 18.71\%, fishing 1.16\%, agricultural laborer 12.3\%, wage laborer $3.54 \%$, industry labour $1.72 \%$, commerce $16.58 \%$, transport $4.523 \%$, construction labour $1.43 \%$, service $24.09 \%$ and others $16.12 \%$.

\section{Urbanization in Chittagong}

ln 1947 the area of the city of Chattogram was only four and half square miles and was centered around the low and small hillocks which were found scattered all over the city. Dampara, Nasirabad, Katalganj. Kapashgola and Solokbahar bound the town on the north, the Karnaphuli on the south. Chaktai null as on the last and Madarbari. Pathantuli and Dewanhat on the west. Originally the town was confined within this limit. With rapid industrialization and development the town soon grew into a city outstripping the old Municipality area. The city extended southwest up to Patenga where the Chattogram International Airport is now located. Its expansion to the west incorporated the villages of Halishahar, Askarabad and Agrabad. The govemment acquired the land at these villages to construct up to Faujdarhat and the Chattogram cantonment area and in the northeast up to Kalurghat.

Total urban area of Chattogram district has expanded from Il20.33sq.km. in 199I to 1254.89 sq. $\mathrm{km}$. in 2001. The Statistical Metropolitan Area increased from $964.66 \mathrm{sq} . \mathrm{km}$. in 1991 to 1034.95 sq.km. in 2001. In 1991 there was only Paurashava in Chattogram district against six Paurashavas in 2001.

Chattogram City Corporation is constituted with 11 thanas of the district namely Bakalia, Bayjid Bostami, Chandgaon, and Chattogram port, Double Mooring, Halishohar, Khulshi, Kotwali, Pahartali, Panchlaish and Patenga. In addition to City Corporation Statistical Metropolitan Area includes the entire areas of Hathazari Upazila, Sitakunda Upazila and Karnafuli Thana. Other Urban Area means the urban area adjoining to city Corporation and Paurashavas. 


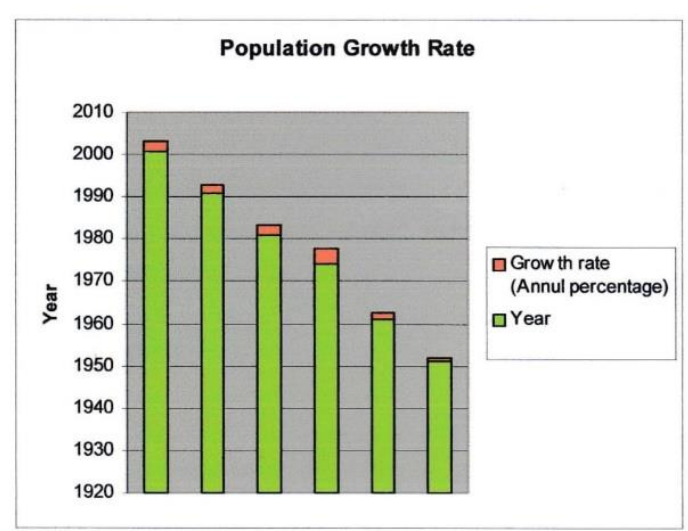

Fig-1: Population Growth Rate

The Concept of Landslide

A landslide or mudslide or hill slide is a geological phenomenon which includes a wide range of ground movement, such as rock falls, deep failure of slopes and shallow debris flows, which can occur in offshore, coastal and onshore environments. All though the action of gravity is the primary)' driving force for a landslide to occur, there are other contributing factors affecting the original slope stability, Typically, pre-conditional factors build up specific sub-surface conditions that make the area/slope prone to failure, whereas the actual Landslide often requires a trigger before being released. (Das \& Raja, 2015; $\underline{\text { Sarwar, 2008) }}$

The History of Landslide incidents in Chattogram city

The historical background of landslide incidents in Chattagram city and its surrounding areas is very alarming. Statistics shows that in 2000, there happened two landslides in Chattogram city in two times, which killed 13 people. But there happened no landslide in 2001. From 2002 to 2004 there happened single landslide in every year and killed 3. In 2003 and 2004- 1 and 5 people respectively. On the contrary, in 2005, it happened four several landslides Chattogram city which caused death of 8 people. In 2007, the most massive landslides took place at seven points in Chattogram City and killed 130 people, which was the highest in landslide incident history of Bangladesh till then. After this huge damage 11 people died by landslide just next year (2008) in Chattogram City. (Mia et al., 2016; Sultana, 2020)

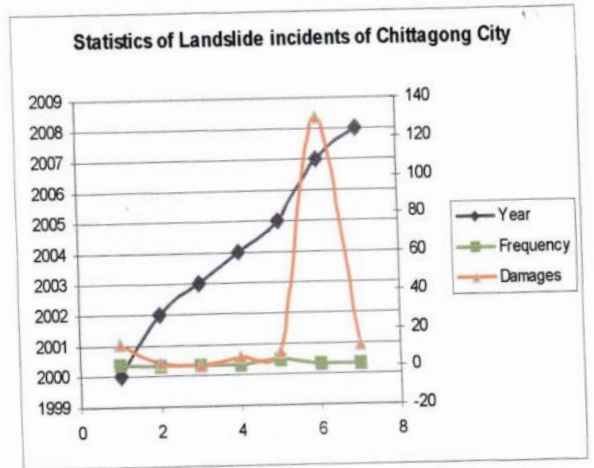

Fig-9: Statistics of Landslide incidents in Chittagong City.

Landslide Affected Areas in Chattogram

In June 2007, landslide happened at main 7 points surrounding Chattogram Metropolitan City. These are:

- Cantonment area's Lebubagan. Sekandor colony and Kachchaguna of Hathazatri Thana.

- Railway's Power Colony area of Pahartali. 
Causes of Landslide and its Socio-economic Effects: a study on Chattogram City and Surrounding Areas, Bangladesh

Ali

- Khulshir Dhebarparh area.

- Armed Police Battalion (APBN) Colony area.

- Shahid Minar area of Chittagong University.

- Motijharnaarea of Lalkhan Bazar.

- Batali Hill of tiger pass.

The below map shows the landslide affected areas of chattogram-

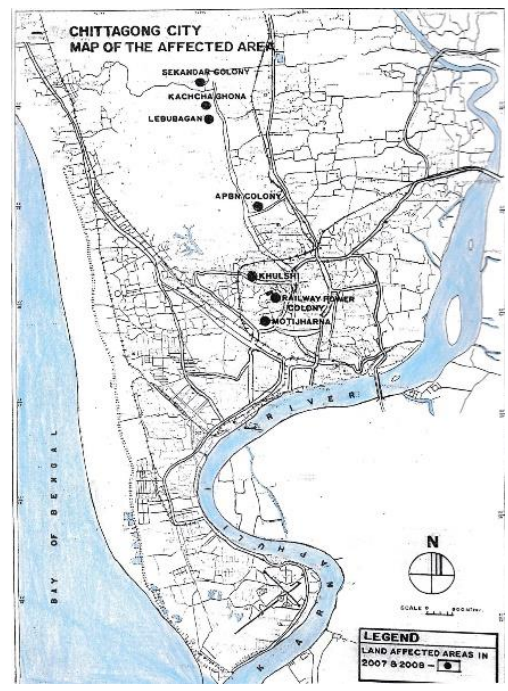

Survey Analysis

The Socio-economic survey was conducted conducted upon 49 persons in total of two categories. The responded persons among the settlers were -11 and the rest was just 8 . The percentages of the male and female responded people were 68.29 and 31.71 accordingly (Table1). Interestingly all the respondent settlers are Bengali Muslims. $75.61 \%$ people among the respondent settlers build their houses at the foothills, 9.76\% settler people at the hill slopes and $14.63 \%$ in plains, which is very close to hills (Fig: 5)

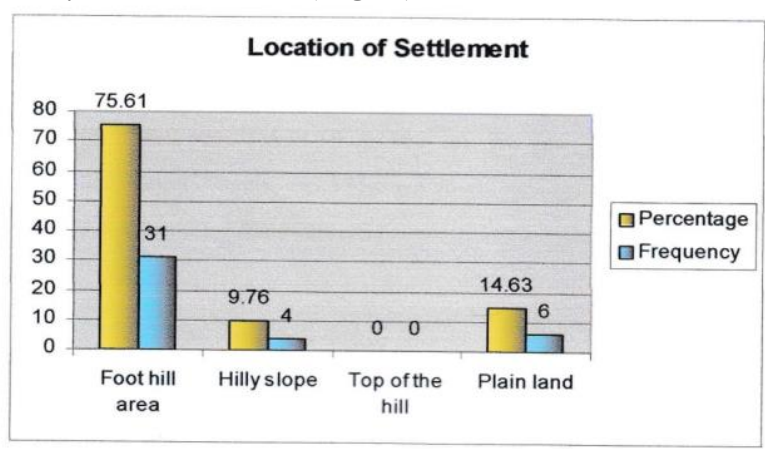

Fig-5: Location of Settlement

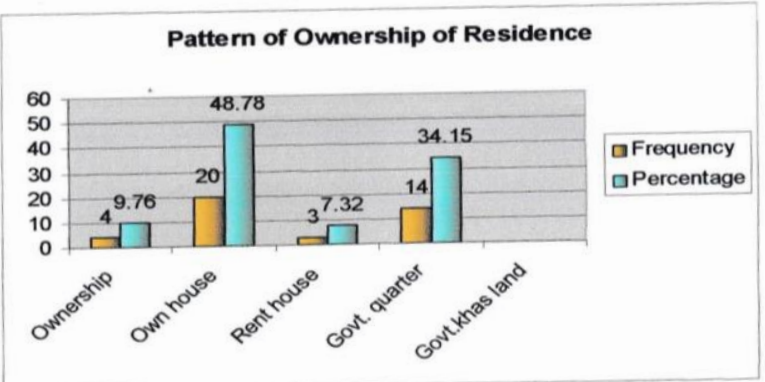

Fig-7: Pattern of Ownership of Residence 


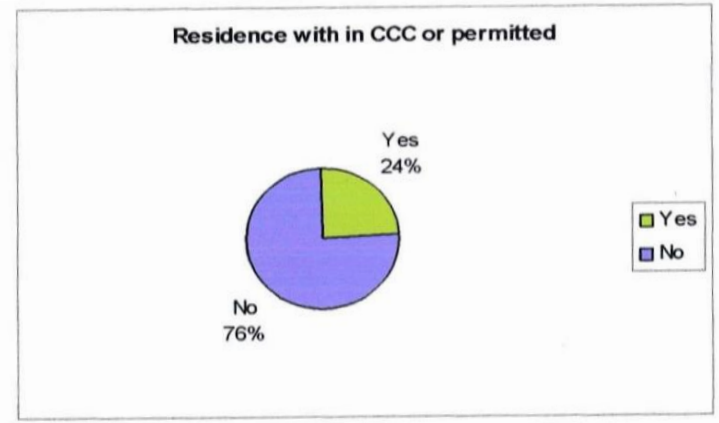

Fig-6: Residence with in CCC or Permitted

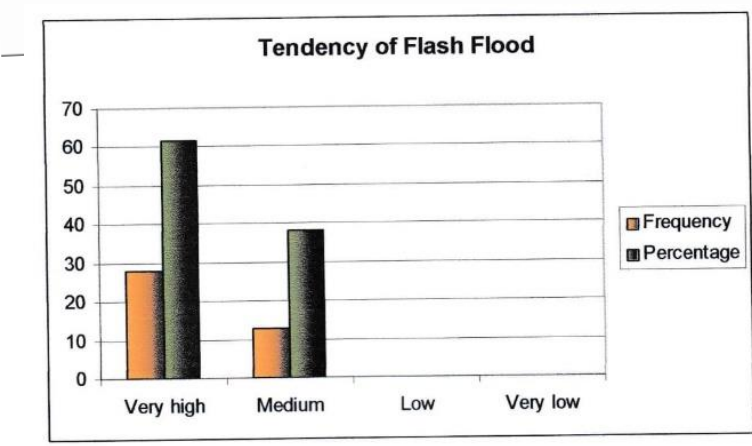

Fig-8: Tendency of flash flood/flood

Causes of Landslide in Chattogram

Landslide is happened when the stability of a slope changes from a stable to an unstable condition. A change in the stability of a slope can be caused by a number of factors, acting together or alone. From the study, it is observed that, there are some causes, which are responsible for Landslides in Chattogram. These are as follows:

1. Slope Instability by Land Degradation: The steepness of a hill is the main factor for the movernment of materials (soil or mud or debris) that flow down towards the foot of the hill. Steep slope push down quickly debris or mud converting gravitational energy into kinetic energy. Every natural hill has a stable surface and keeps a balance of its components. But sometimes, it loses its balance by man's inhuman activities. Landslides of Chattogram in 2007 and 2008 are the two authentic examples for such misdeeds. For rapid urbanization, increasing of house rent and land value to supply soils in brick kiln industries and for the purpose of construction roads, new buildings or culverts soils are extracted haphazardly and unplanned way in Chattogram city area. A study (Quddusi, 2007) referred that more than 100 hills have been raised in last 30 years in Chattogram region. Another study (lslam. 2008) referred that hills of Chittagong region are cut slopping $70 \neg$ or more angle. This inhuman and relentless activities resulted landslide in Chattogram in the previous ) years.

2. Deforestation: It is another important cause for landslides in Chattogram region. Hills are first deforested for soil extraction imposing the land surface of the hill increasing its vulnerability to erosion. This is because, soils of open hill surface absorb rainwater quickly which dissolve soils nutrient losing its compaction. Slope instability and loose wet or muddy soil, which absorbs rainwater, cannot hold extra weight which results downward soil movement as landslide.

3. Heavy Rainfall with Earthquake: It is keenly observed that a heavy rainfall within a shorter period of time always led to a large scale of landslide in Chittagong area Landslides of Chittagong in 2007 and 2008 are two instances of it. Chattogram Meteorological Department declared that, before the landslide incident of 2007 in Chattogram the total rainfall recorded $267 \mathrm{~mm}$ in a day. Such a huge amount of rainfall in such a shorter duration of time adding 
earthquake triggered landslide in Chattogram region. This is because, hilly uncovered topsoil is compounds, dissolved and loss the strength of compaction and finally occurs landslide in unstable hills.

4. Rapid urbanization, Housing problem and unplanned Settlement: Lack of employment opportunities in rural areas, on the other hand industrialization business or other income generating opportunities in urban areas people emigrate Chattogram city from nearby districts. Sometimes river eroded or cyclone or flood affected people gathers in city to survive a little. These poor and pro-poor people live in cheaper rented houses built in close foot hills or sometimes live at hill slopes. Most of these houses are built cutting hills in unplanned ways. The people who live in such places, most of the time are targeted of landslide.

5. Global Warming: It is another important factor of landslide. Bangladesh has experienced effects of global warming from various aspects in recent years. Due to global Weather factors behaving irregularities. It has been seen that, it does not rain in time. Most of the year, either rainy season comes late or sometimes comes sooner after along dry and hot weather. Due to hot weather in day time and low temperature at night top soils of hills weathered (especially in deforested hills where hills are composed of clay and sand) become loose and loses its soil compaction strength, when torrential rains last two or three days or more adding a little earth quake it occurs landslides with heavy loss of life and wealth which is a very common picture in Chittagong and its surrounding hilly areas of now a days.

6. Jhum Cultivation: It is one of the causes of landslide. Hilly people practiceJhumcultivation after deforesting and trenching soil as traditional to these areas. Thus.topsoils become loose, absorb rainwater and triggers landslide.

7. Increase of Population: Now a days, the flow of population has increased at an alarming rate in hilly areas for different socio-economic causes. These floating people misuse of hilly lands in different ways and increase the frequency of such disasters.

8. Presence of Greedy and influential people: There are some greedy and influential people who are always active in hill cutting activities managing different authorities which finally led to landslide.

Socio-economic Effects of Landslide

Effects of landslide are horrible. This is because, it happens within a few seconds. It does not give any scope of escaping from the affected area. It rushes tons of mud or soil or stone within a few seconds without alarming anybody. It always brings sorrows and sufferings from family to state level. Some of these are:

1. Continuous and rampant landslides cause loss of lives and properties. Most of the time, it devastates the whole family, with all properties or sometimes it makes at a loss of a single survivor of a family.

2. Sometimes it poses serious threat to other existing buildings-Government or private owned, where hill shape is changed.

3. Heavy loss of life and properties is always a state concern. Government has to pay a great compensation for landslide recovery. This is because, Government has to arrange food and shelter, clothing and treatment for the affected and vulnerable evacuated people. Sometimes, it needs to repair and reconstruct houses, roads and culverts.

4. Sometimes, houses and roads are blocked and remain disconnected from other parts of the city or country, which lingers the sufferings of affected people. Not only this, sometimes rescue or aid suppliers cannot reach to those people.

5. Sometimes, affected people have to take shelter in refugee camps or Government owned buildings and has to led a miserable life. 
6. Most of the time, affected people have to change their previous occupation losing all properties in landslides.

7. Some injured and physically disabled people survived from landslide have to led on other members of family as a burden rest of their life.

8. Sometimes, trees and shrubs fell with landslide. Thus, forest resources are hampered by landslide. Finally, it causes threat to eco-system.

9. Women and children suffer/affect the most by landslide. This is because, women physically weak by born and like to stay at homestead. In the same line, children also stay home most of the time. This is why, these two groups suffer the most by landslide.

10. Hill shape is changed to Shrunken where it rampant landslides. Therefore, topography of a particular region is changed finally.

On the basis of analysis, of causes and way out of landslide in Chattogram the following mitigating measures are suggested as way out of this incident, which can play an important role to keep an eco-friendly hilly environment and will be able to keep disaster

free in future years. These are:

1. A strong hill preservation committee must be formed with different experts like Geographer/Environmentalists, Geologist, Planner, Hydrologist, Climatologist, Economist, Sociologist, Administrative Judge, Political leader etc. Who will look after the hills and will take necessary legal actions against the unabated hill cutters.

2. In this connection, it is needed to be said that, existing Environmental Laws in the country must be upgraded.

3. The body (The Hill Presentation Committee) could also play an important role in people especially in the hilly settlers to increase awareness of unabated hill cutting and risky settlements through Seminar, Symposium, Meeting, making poster, and leaflet through print and electronic media.

4. All illegal settlers must be evacuated from the foothills, hill pockets and hill slopes and rehabilitate to safer places like Government khash lands. A healthy fund must be created for this purpose. The responsibility may be given to the "Hill Presentation Committee"(HPC). They will carry on the duty and prohibit people establishing any kind of settlement at vulnerable hilly areas. At the same time Security fences round the exposed hill slopes to prevent the potentiality of illegal settlement development further.

5. Any kind of change and development activities in the hilly areas must be performed through the concern/permission of Hill Preservation Committee (HPC). It will act, as an independent body and must be entitled with supreme Authorization Power. The HPC will look into the matter. It may only give permission of development work in case of national need like National Highway or Rail, Track or like national security matter development activities and not for other purposes.

6. Deforested/Barren hills must be taken under afforestation program immediately. Trees protect hills in various ways. Roots of trees stabilize the strength of soil compaction as cementing material and reduce soil erosion. In the same line, vegetation preserves soils from erosion protecting sunrays and raindrops as an umbrella.

7. All kinds of unplanned development activities (private or Government) must be stopped from now.

8. Flash Flood water stagnant is a common picture in Chattogram City. This is because, the drainage system is very poor. City's drainage system should be improved immediately to drain out city's rainwater. In this connection, canal grabbers should be removed and the flow of rainwater through canals should be ensured for the improvement of water logging situation.

9. When landslide is occurred, very often a blame game is seen, within various departments/Organizations it should be stopped. At the same time, it should be established 
a good governess with transparency and accountability. To avoid this problem, retention walls can be constructed between the territories of various departments.

10. A landslide hazard Mitigation related rescue Operation Contingency should be formed immediately and permanently at Chittagong based. The contingency may be formed both in Government and Community level with a strong co-ordination body. It should be well equipped with rescue tools and well trained. So that, they could perform instantly in case of emergency situation.

11. It is obvious that, most of the landslides have been occurred in time of continuous intense rainfall. This is why, landslide warnings should be reached to the relevant people through different medias- like print and electronic media, Mobile SMS and announce by mike/loudspeaker. So that, vulnerable hilly people could be taken shelter to a safer place when danger would come.

12. The people who have taken shelters in foothills, hill pockets and hill slopes are pro-poor. Most of them are either river eroded or Cyclone affected or flood affected people. They have lost their land and property. So, Government should address their shelter and poverty. They should be taken under the Social Safetynet programme of the Government. NGos can play an important role in this connection. If they are assured of minimum food and shelter, it is expected that they will not go back to hilly areas farther.

13. A landslide database is essential to be developed as early as possible through geomorphological and geophysical survey. It could be helpful to find out the most actual causes and trends of landslide through studies. Moreover, a landslide vulnerable mapping should be established through the survey and more landslide vulnerable areas should bemarked as Red-Zone. For housing or any kind of development activities this Red-Zone should be marked with proper Sign Board and fencing or Retention wall, using a modem technology that is Geographic information system (GIS) and Remote Sensing (RS) which perform this important task.

14. Last of all a Detailed Area planning (DAP) of Chittagong City should be developed by zoning according to the use of land. It should be followed by stakeholders and would be implemented strictly by a good governance system with Transparency and accountability.

\section{CONCLUSION}

In Conclusion, it can be said that hill cutting and heavy rainfall with earthquake are main factors for landslides in Chattogram, which causes death to hundred people with a great loss of property and domestic animals. This scenario could be kept at a minimum level by strictly checking land grabbing that is hill-cutting activities by influential and resettling the risky settlers to safer places from hill areas. Experts from different organizations should establish high-powered Hill Preservation Committee (HPC) immediately and permanently. A Detailed Area Planning (DAP) with zoning of the city is very essential. In the same line, landslide database and landslide vulnerable mapping through geophysical and geological analysis of the city is essential to minimize landslides and its impacts in this region in future years. In addition, a rapid weather forecasting system to be developed with establishing a rainfall database for this region. Furthermore, a Rapid Rescue Operation Contingency (ROC) should be established with modern tools and proper training that will take necessary actions in crisis period to minimize the hazard. Finally, a social and environmental awareness developing scheme should be taken through different medias like meeting, seminar, symposium, cinema, drama and different programmes by Television and Radio. Last of all, the vulnerable people of the hilly region must be brought under social safety net programme.

\section{REFERENCES}

Abedin, J., Rabby, Y. W., Hasan, I., \& Akter, H. (2020). An investigation of the characteristics, causes, and consequences of June 13, 2017, landslides in Rangamati District Bangladesh. 
Causes of Landslide and its Socio-economic Effects: a study on Chattogram City and Surrounding Areas, Bangladesh

Ali

Geoenvironmental Disasters, 7(1), 23. https://doi.org/10.1186/s40677-020-00161-z

Ahmed, B. (2021). The root causes of landslide vulnerability in Bangladesh. Landslides, 18(5), 1707-1720. https://doi.org/10.1007/s10346-020-01606-0

Bounab, A., El Kharim, Y., El Hamdouni, R., \& Hlila, R. (2021). A multidisciplinary approach to study slope instability in the Alboran Sea shoreline: Study of the Tamegaret deep-seated slow-moving landslide in Northern Morocco. Journal of African Earth Sciences, 184, 104345. https://doi.org/10.1016/j.jafrearsci.2021.104345

Carabella, C., Cinosi, J., Piattelli, V., Burrato, P., \& Miccadei, E. (2022). Earthquake-induced landslides susceptibility evaluation: A case study from the Abruzzo region (Central Italy). CATENA, 208, 105729. https://doi.org/10.1016/j.catena.2021.105729

Chen, C., Li, H., Chen, J., Zhang, J., Zhang, L., \& Tang, X. (2021). Overtopping and flood routing process of landslide dams consisted of ice-soil mixtures: A preliminary study. Journal of Hydrology, 127252. https://doi.org/10.1016/j.jhydrol.2021.127252

Das, S., \& Raja, D. R. (2015). Susceptibility analysis of landslide in Chittagong City Corporation Area, Bangladesh. International Journal of Environment, 4(2), 157-181. https://doi.org/10.3126/ije.v4i2.12635

Islam, A. (2017). Landslides in Chittagong Hill Tracts And Possible Measures. International $\begin{array}{llllll}\text { Conference on Disaster Risk Mitigation (ICDRM), } & 2017, & 12 .\end{array}$ https://doi.org/http://dx.doi.org/10.13140/RG.2.2.25254.83520

Liu, X., Zhao, C., Zhang, Q., Yin, Y., Lu, Z., Samsonov, S., Yang, C., Wang, M., \& Tomás, R. (2021). Three-dimensional and long-term landslide displacement estimation by fusing Cand L-band SAR observations: A case study in Gongjue County, Tibet, China. Remote Sensing of Environment, 267, 112745. https://doi.org/10.1016/j.rse.2021.112745

Meghanadh, D., Kumar Maurya, V., Tiwari, A., \& Dwivedi, R. (2021). A multi-criteria landslide susceptibility mapping using deep multi-layer perceptron network: A case study of SrinagarRudraprayag region (India). Advances in Space Research. https://doi.org/10.1016/j.asr.2021.10.021

Mia, M., Sultana, N., \& Paul, A. (2016). Studies on the Causes, Impacts and Mitigation Strategies of Landslide in Chittagong city, Bangladesh. Journal of Environmental Science and Natural Resources, 8(2), 1-5. https://doi.org/10.3329/jesnr.v8i2.26854

Panchal, S., \& Shrivastava, A. K. (2021). Landslide hazard assessment using analytic hierarchy process (AHP): A case study of National Highway 5 in India. Ain Shams Engineering Journal. https://doi.org/10.1016/j.asej.2021.10.021

Pawluszek-Filipiak, K., Borkowski, A., \& Motagh, M. (2021). Multi-temporal landslide activity investigation by spaceborne SAR interferometry: The case study of the Polish Carpathians. Remote Sensing Applications: Society and Environment, 24, 100629. https://doi.org/10.1016/j.rsase.2021.100629

Sarwar, G. M. (2008). Landslide Tragedy of Bangladesh. The First World Landslide Forum, 11. https://www.academia.edu/3588839/Landslide_Tragedy_of_Bangladesh?auto=download

Sultana, N. (2020). Analysis of landslide-induced fatalities and injuries in Bangladesh: 2000-2018. Cogent Social Sciences, 6(1), 1737402. https://doi.org/10.1080/23311886.2020.1737402

Wistuba, M., Gorczyca, E., \& Malik, I. (2021). Inferring precipitation thresholds of landslide activity from long-term dendrochronological and precipitation data: Case study on the unstable slope at Karpenciny, Poland. Engineering Geology, 294, 106398. https://doi.org/10.1016/j.enggeo.2021.106398 